\title{
PENGGUNAAN BAHASA ILMIAH \\ PADA PENULISAN SKRIPSI: \\ PROBLEMATIKA DAN ALTERNATIF SOLUSINYA \\ (Studi Kasus Mahasiswa Jurusan Pendidikan Agama Islam \\ IAIN Syekh Nurjati Cirebon)
}

\author{
Tati Sri Uswati \\ IAIN Syekh Nurjati \\ tatisriuswati@gmail.com
}

\begin{abstract}
Abstrak
Skripsi merupakan tugas akhir penulisan bagi mahasiswa sebagai salah satu dokumen penting yang merepresentasikan prestise institusi. Masih banyak ditemukan kesalahan atau ketidaksesuaian dengan prinsip-prinsip ragam bahasa ilmiah dalam penulisan skripsi. Oleh karena itu, penelitian mengenai hal tersebut perlu dilakukan. Penelitian ini bertujuan untuk: 1) mendeskripsikan penggunaan bahasa ilmiah pada penulisan skripsi mahasiswa Jurusan Pendidikan Agama Islam IAIN Syekh Nurjati Cirebon, 2) mendeskripsikan jenis kesalahan penggunaan bahasa ilmiah pada skripsi jurusan tersebut, 3) memperbaiki kesalahan-kesalahan penggunaan bahasa ilmiahnya, dan 4) mendeskripsikan problematika penulisan bahasa ilmiah dan alternatif solusinya. Data penelitian diambil secara acak sebesar 20\% (24 skripsi) dari jumlah populasi sebanyak 120 skripsi. Metode yang digunakan adalah kualitatif deskriptif. Berdasarkan hasil analisis kesalahan dari data tersebut, ditemukan 31 kesalahan pembentukan kata, 61 kesalahan pemilihan kata, 62 kesalahan penyusunan kalimat, 11 kesalahan penataan penalaran, dan 105 kesalahan penerapan kaidah ejaan. Di samping itu, ada delapan abstrak dengan penulisan klausa akhirnya menggunakan kata-kata yang sama, tetapi hitungan persentasenya berbeda. Terdapat pula delapan judul skripsi yang diawali dengan kata pengaruh.
\end{abstract}

Thesis is the final project of writing for students as one of the important document that represents the prestige of the institution. There are still many errors or incompatibility with the principles of the scientific diversity of languages in the thesis. Therefore, research needs to be done about it. This study aims to: 1) describe the use of scientific language on the writing of students of Department of Islamic Education IAIN Syekh Nurjati Cirebon, 2) describes the types of errors using scientific language in the thesis of the department, 3) fix the mistakes the use of scientific language, and 4) writing scientific language to describe the problems and alternative solutions. Data were taken randomly by $20 \%$ (24 thesis) of a total population of 120 thesis. The method used is descriptive qualitative. Based on the analysis of data errors, word formation found 31 errors, 61 errors word choice, sentence drafting error 62, 11 arrangement error of reasoning, and the application of rule 105 spelling errors. In addition, there are eight abstract by writing clauses ended up using the same words, but a matter of a different percentage. There are also eight title essay that begins with the word influence.

Kata kunci: bahasa, ilmiah, penulisan, problematika, skripsi 


\section{A. Pendahuluan}

Bahasa Indonesia memiliki tiga status. Pertama, sebagai bahasa nasional yang disandang sejak munculnya gerakan kebangkitan nasional pada awal abad XX. Dalam kedudukannya sebagai bahasa nasional, bahasa Indonesia berfungsi sebagai lambang kebanggaan nasional, lambang identitas nasional, alat pemersatu berbagai masyarakat yang berbeda latar belakang sosial budayanya serta alat perhubungan antarbudaya dan antardaerah. Kedua, sebagai bahasa persatuan yang disandang sejak 28 Oktober 1928, yaitu diikrarkannya Sumpah Pemuda yang menyatakan “... menjunjung tinggi bahasa persatuan, yaitu bahasa Indonesia". Ketiga, sebagai bahasa negara yang disandang sejak dicantumkannya dalam Undang-Undang Dasar 1945. Dalam kedudukannya sebagai bahasa negara, bahasa Indonesia berfungsi sebagai bahasa resmi kenegaraan, bahasa pengantar dalam dunia pendidikan, bahasa resmi dalam perhubungan pada tingkat nasional untuk kepentingan perencanaan dan pelaksanaan pembangunan serta pemerintahan, dan bahasa resmi dalam pengembangan kebudayaan dan pemanfaatan iptek.

Mengingat sejarah, fungsi, dan kedudukan bahasa Indonesia tersebut, sudah selayaknya kita menunjukkan karakter berbahasa Indonesia secara baik dan benar sebagai perwujudan rasa cinta dan bangga berbahasa Indonesia karena "bahasa menunjukkan bangsa" atau bahasa menunjukkan peradaban penuturnya. Di dalam bahasa akan timbul kesan bahwa para pemakainya tidak menghormati kewibawaan bahasanya sendiri bila banyak orang secara sadar menyimpang dari kaidah yang telah disepakati atau diberlakukan. Hal ini sesuai dengan pendapat Kuntjaraningrat (1992) yang mengatakan bahwa kebanyakan orang Indonesia yang berbahasa Indonesia berprinsip “pokoknya mengerti”. Namun, pada umumnya penyimpangan atau kesalahan itu dilakukan karena ketidaktahuan atau ketidaksengajaan.

Penyimpangan atau kesalahan kaidah kebahasaan akan mudah diketahui dan dianalisis pada penggunaan bahasa tertulis, termasuk pada penulisan skripsi. Skripsi adalah karya tulis ilmiah berupa paparan tulisan hasil penelitian sarjana S1 yang membahas suatu permasalahan/fenomena dalam bidang ilmu tertentu dengan menggunakan kaidah-kaidah yang berlaku. Sebagai sebuah karya ilmiah, skripsi harus menggunakan kaidah kebahasaan yang berlaku dalam penulisan akademik, yaitu dengan menerapkan ciri bahasa ilmiah. Bahasa ilmiah lebih menekankan pada segi kelugasan, 
ketepatan, dan kebakuan. Maksudnya, mematuhi kaidah-kaidah gramatika; menggunakan kosakata baku, dan mematuhi kaidah-kaidah ejaan yang berlaku.

Skripsi adalah karangan ilmiah yang disusun sebagai tugas akhir dalam pendidikan Strata 1 (S1). Oleh karena itu, sebagai tugas akhir yang mendapat bimbingan khusus, penulisan skripsi seyogyanya sudah memperlihatkan penggunaan bahasa ilmiah yang lebih baik daripada penulisan karya-karya ilmiah sebelumnya.

Namun, permasalahannya sesuai hasil pengamatan terhadap penggunaan bahasa pada skripsi mahasiswa, gambaran/ciri-ciri ragam bahasa ilmiah tersebut masih belum sesuai dengan yang diharapkan. Mahasiswa cenderung mengabaikan dimensi-dimensi kebahasaan di dalam kaya tulis ilmiah akademis. Masih banyak ditemukan kesalahankesalahan atau ketidaksesuaian dengan prinsip-prinsip bahasa ilmiah, misalnya banyak penulisan kalimat yang bermakna ambigu, penulisan kata yang tidak baku, struktur kalimat yang rancu, kalimat yang kurang logis, dan penulisan preposisi yang tidak tepat. Padahal penggunaan bahasa yang baik dan benar akan turut menentukan kualitas skripsi, yang notabene adalah dokumen yang merepresentasikan prestise institusi.

Sesuai dengan uraian tersebut, penelitian yang berjudul Penggunaan Bahasa Ilmiah pada Penulisan Skripsi: Problematika dan Alternatif Solusinya (Studi Kasus Mahasiswa Jurusan Pendidikan Agama Islam IAIN Syekh Nurjati Cirebon) dipandang perlu dan tepat untuk dilaksanakan guna meningkatkan kualitas dan kefektifan pembimbingan dan pembelajaran menulis pada mata kuliah Bahasa Indonesia di IAIN Syekh Nurjati Cirebon.

Berdasarkan latar belakang yang telah diuraikan, rumusan masalahnya adalah sebagai berikut. Pertama, bagaimanakah penggunaan bahasa ilmiah pada penulisan skripsi mahasiswa Jurusan Pendidikan Agama Islam (PAI) IAIN Syekh Nurjati Cirebon? Kedua, apa sajakah jenis kesalahan penggunaan bahasa ilmiah pada skripsi mahasiswa Jurusan PAI IAIN Syekh Nurjati Cirebon? Ketiga, bagaimanakah perbaikan kesalahan-kesalahan penggunaan bahasa ilmiah pada skripsi mahasiswa Jurusan PAI IAIN Syekh Nurjati Cirebon? Keempat, apa sajakah problematika penulisan ilmiah dan alternatif solusinya pada penulisan skripsi mahasiswa Jurusan PAI IAIN Syekh Nurjati Cirebon?

Sesuai dengan rumusan masalah, penelitian ini dilakukan dengan tujuan untuk (1) mengetahui penggunaan bahasa ilmiah pada penulisan skripsi mahasiswa Jurusan Pendidikan Agama Islam (PAI) IAIN Syekh Nurjati Cirebon, (2) mengetahui jenis 
kesalahan penggunaan bahasa ilmiah pada skripsi mahasiswa Jurusan PAI IAIN Syekh Nurjati Cirebon?, (3) memperbaiki kesalahan-kesalahan penggunaan bahasa ilmiah pada skripsi mahasiswa Jurusan PAI IAIN Syekh Nurjati Cirebon, (4) mengetahui problematika penulisan bahasa ilmiah dan alternatif solusinya pada penulisan skripsi mahasiswa Jurusan PAI IAIN Syekh Nurjati Cirebon.

\section{B. Metode Penelitian}

Tahapan yang dilakukan dalam penelitian ini adalah tahap pengumpulan data, tahap analisis data, dan tahap penyajian hasil analisis data. Pengumpulan data dilakukan dengan mengumpulkan skripsi mahasiswa jurusan Pendidikan Agama Islam (PAI) angkatan 2015 yang dijadikan populasi dalam penelitian ini. Data penelitian diambil secara acak sebesar $20 \%$ atau 24 skripsi dari jumlah populasi sebanyak 120 skripsi. Setelah data terkumpul, dilanjutkan dengan menganalisisnya. Metode yang digunakan adalah kualitatif deskriptif. Metode kualitatif merupakan prosedur penelitian yang menghasilkan data deskriptif berupa kata-kata tertulis atau lisan dari orang-orang dan perilaku yang dapat diamati (Bogdan dan Taylor, 1975:5 dalam Moleong, 2013:4).

Tahap analisis data dimulai dengan mengidentifikasi dan menganalisis 71 kalimat yang dijadikan sebagai kasus yang diambil dari 24 abstrak skripsi. Selanjutnya setiap data/kalimat tersebut diklasifikasikan berdasarkan kemungkinan jenis-jenis atau tipetipe kesalahan yang berkaitan dengan penggunaan bahasa Indonesia ragam ilmiah yang baik dan benar, yaitu (1) kesalahan pembentukan kata, (2) kesalahan pemilihan kata, (3) kesalahan penyusunan kalimat, (4) kesalahan penataan penalaran, dan (5) kesalahan penerapan kaidah ejaan (Arifin dan Hadi, 2001). Data yang sudah diidentifikasi dan diklasifikasikan tersebut kemudian dideskripsikan jenis/tipe kesalahannya dan alternatif pembenahannya. Tahap terakhir adalah tahap penyajian hasil analisis. Tahap ini dilakukan dengan memaparkan atau mendeskripsikan temuan-temuan yang dijumpai dalam penelitian.

\section{Hasil dan Pembahasan}

Setelah penelitian selesai dilaksanakan, hasil penelitian ini dapat diuraikan sebagai berikut. Data dalam penelitian ini berupa 71 kalimat dari 24 abstrak skripsi mahasiswa Jurusan Pendidikan Agama Islam (PAI) IAIN Syekh Nurjati Cirebon angkatan 2015. Data yang telah terkumpul tersebut kemudian dianalisis, diklasifikasi, dan dideskripsikan 
berdasarkan jenis-jenis kesalahan, yaitu kesalahan yang termasuk pada pembentukan kata, pemilihan kata, penyusunan kalimat, penataan penalaran, dan penerapan kaidah ejaan. Selanjutnya, kesalahan-kesalahan data tersebut dicari alternatif perbaikan/pembenahannya.

Contoh analisis, klasifikasi kesalahan, dan hasil temuannya adalah sebagai berikut.

\section{Kasus Abstrak 1:}

(1a) Pentingnya kegiatan keagamaan seperti Marhabanan terhadap pendidikan agama remaja sangat dibutuhkan.

(1b) Sebagaimana dalam pengamatan penulis bahwa perilaku keagamaan remaja di Desa Kanci sangat perlu untuk diperbaiki karena banyak hal yang terjadi pada perilaku remajanya.

(1c) Remaja yang mengikuti kegiatan Marhabanan Masjid Al-Karomah yang diharapkan memiliki perilaku Keagamaan yang baik pada dirinya, akan tetapi mereka melakukan hal-hal yang tidak baik untuk dilakukan seperti sering meninggalkan sholat wajib lima waktu, tidak jujur, tidak menghormati orang yang lebih tua dan lain-lain.

\section{Analisis Kasus (1a)}

Pada kasus (1a) terdapat satu kesalahan penataan penalaran.

\section{Kesalahan Penataan Penalaran (1a)}

Kalimat tersebut tampaknya singkat, tetapi kurang efektif karena secara semantik kurang lugas sehingga tidak jelas maksudnya.

\section{Alternatif pembenahan kalimat (1a):}

Kegiatan keagamaan, seperti marhabanan, memiliki peran penting terhadap pendidikan agama remaja. Oleh karena itu, keberadaannya sangat dibutuhkan.

\section{Kasus Abstrak (1b)}

Sebagaimana dalam pengamatan penulis bahwa perilaku keagamaan remaja di Desa Kanci sangat perlu untuk diperbaiki karena banyak hal yang terjadi pada perilaku remajanya.

\section{Analisis Kasus (1b)}

Pada kasus (1b) terdapat 3 kesalahan pemilihan kata, 1 kesalahan penyusunan kalimat, dan 1 kesalahan penataan penalaran 


\section{Kesalahan Pemilihan Kata (1b)}

Pada kalimat (1b) terdapat pleonasme, yaitu penggunaan kata yang tidak ekonomis karena terdapat kata-kata yang sebetulnya tidak perlu digunakan. Pada kalimat yang sama, kata/frasa perilaku remaja mengalami pengulangan. Jadi, pada perilaku remajanya hendaknya dihilangkan. Pada kalimat itu terdapat penggunaan kata yang tidak hemat karena tidak jelas maksudnya; tidak diperlukan, yaitu karena banyak hal yang terjadi.

Pada penulisan karangan ilmiah, tidak diperbolehkan menggunakan pilihan kata yang mengekspresikan data secara subjektif. Oleh karena itu, jangan menggunakan kata saya, kami, penulis, atau peneliti. Pada kalimat (1b) terdapat kata dalam pengamatan penulis; seharusnya kata penulis dihilangkan.

\section{Kesalahan Penyusunan Kalimat (1b)}

Pada kalimat (1b) terdapat dua buah konjungsi, yaitu sebagaimana dan bahwa. Dengan adanya dua konjungsi tersebut, tidak diketahui unsur mana sebagai induk kalimat dan unsur mana sebagai anak kalimat. Sebagaimana dalam pengamatan penulis bahwa perilaku keagamaan remaja di Desa Kanci sangat perlu untuk diperbaiki .... Dengan demikian, kedua unsur itu merupakan anak kalimat. Jadi, kalimat (1b) tidak mempunyai induk kalimat. Kalau begitu, satu konjungsi harus dihilangkan supaya satu dari dua unsur itu menjadi induk kalimat.

\section{Kesalahan Penataan Penalaran (1b)}

Secara semantik, bahwa perilaku keagamaan remaja di Desa Kanci sangat perlu untuk diperbaiki apabila dihubungkan dengan kalimat berikutnya ... akan tetapi mereka melakukan hal-hal yang tidak baik ... sering meninggalkan sholat wajib lima waktu, tidak jujur, tidak menghormati orang yang lebih tua.... kalimat (1b) tidak memenuhi persyaratan penalaran karena kurang logis/ tidak dapat diterima oleh akal sehat ; maksudnya yang perlu diperbaiki adalah bukan perilaku keagamaan remaja, tetapi perilaku remajanya.

\section{Alternatif pembenahan (1b)}

Berdasarkan hasil pengamatan, perilaku remaja di Desa Kanci sangat perlu untuk diperbaiki.

\section{Atau}

Sebagaimana hasil pengamatan, perilaku remaja di Desa Kanci sangat perlu untuk diperbaiki. 


\section{Kasus Abstrak (1c)}

Remaja yang mengikuti kegiatan Marhabanan Masjid Al-Karomah yang diharapkan memiliki perilaku Keagamaan yang baik pada dirinya, akan tetapi mereka melakukan hal-hal yang tidak baik untuk dilakukan seperti sering meninggalkan sholat wajib lima waktu, tidak jujur, tidak menghormati orang yang lebih tua dan lain-lain.

\section{Analisis Kasus (1c)}

Pada kasus (1c) terdapat 2 kesalahan pemilihan kata, 3 kesalahan penyusunan kalimat, dan 2 kesalahan penerapan kaidah ejaan.

\section{Kesalahan Pemilihan Kata (1c)}

Penggunaan kata yang tidak diperlukan (pleonasme). Pada kalimat tersebut terdapat bentuk pada dirinya tidak diperlukan karena sudah ada kata remaja. Kata untuk dilakukan tidak diperlukan karena sudah ada kata melakukan.

\section{Kesalahan Penyusunan Kalimat (1c)}

Menempatkan kata yang di depat predikat. Kalimat yang tidak mempunyai predikat terjadi, antara lain, akibat adanya keterangan subjek yang beruntun, kemudian keterangan itu diberi keterangan lagi sehingga penulisnya terlena dan lupa kalau kalimat yang dibuatnya itu belum lengkap, belum berpredikat, misalnya sebelum predikat tersebut dicantumkan kata yang atau dan sehingga predikat kalimat menjadi hilang. Pada kalimat (1a) Kehadiran kata yang sebelum kata diharapkan akan mengakibatkan kalimat tersebut kehilangan predikat. Oleh karena itu, kata yang sebelum kata diharapkan harus dibuang.

Kata dan lain-lain tidak diperlukan karena sebelum rincian sudah ada seperti. Dalam perincian dari kata seperti, misalnya, contohnya, antara lain, atau umpamanya jangan gunakan kata dan lain lain (dll) atau dan sebagainya (dsb)

Dalam kalimat itu juga terdapat kata penghubung antarkalimat di tengah kalimat Akan tetapi adalah konjungsi antarkalimat; seharusnya digunakan pada awal kalimat, bukan di tengah kalimat.

\section{Kesalahan Penerapan Kaidah Ejaan (1c)}

Penempatan tanda koma

1) Tanda koma sebelum akan tetapi tidak diperlukan karena akan tetapi merupakan konjungsi antarkalimat.

2) Sebelum akan tetapi seharusnya titik (.); Sesudah akan tetapi dan sebelum seperti seharusnya diberi tanda koma (,) 


\section{Alternatif Pembenahan (1c)}

Remaja yang mengikuti kegiatan Marhabanan Masjid Al-Karomah diharapkan memiliki perilaku keagamaan yang baik. Akan tetapi, mereka berperilaku tidak baik, seperti sering meninggalkan sholat wajib lima waktu, tidak jujur, dan tidak menghormati orang yang lebih tua.

\section{Kasus Abstrak 2 :}

(2a) EFEKTIFITAS PENGGUNAAN METODE SOROGAN TERHADAP KEMAMPUAN DALAM MEMBACA KITAB FATHUL AL-QORIB SANTRI USIA 13-15 TAHUN DI PONDOK PESANTREN ASSALAFIYAH DESA LUWUNGRAGI KECAMATAN BULAKAMBA KABUPATEN BREBES

(2b) Secara umum Pesantren memiliki beberapa macam metode yang digunakan dalam kegiatan pembelajaran kitab kuning, salah satunya adalah metode sorogan, dimana metode ini dilakukan secara tatap muka langsung antara kyai/ustadz dan santri.

(2c) Apabila metode ini dapat dilaksanakan dengan baik, maka akan menciptakan kemampuan membaca kitab dengan baik.

(2d) Kemampuan santri usia 13-15 tahun dalam membaca kitab fathul qorib di pondok pesantren assalafiyah desa luwungragi Kecamatan Bulakamba Kabupaten Brebes dirasakan kurang, padahal telah diterapkan metode sorogan oleh' ustadz yang berkompeten di bidangnya.

Analisis Kesalahan Judul, Kasus Abstrak (2a):

EFEKTIFITAS PENGGUNAAN METODE SOROGAN TERHADAP KEMAMPUAN

DALAM MEMBACA KITAB FATHUL AL-QORIB SANTRI USIA 13-15 TAHUN DI PONDOK PESANTREN ASSALAFIYAH DESA LUWUNGRAGI KECAMATAN BULAKAMBA KABUPATEN BREBES

\section{Analisis Kasus (2a)}

Pada kasus (2a) terdapat satu kesalahan pemilihan kata dan tiga penerapan kaidah ejaan.

\section{Kesalahan Pemilihan Kata (2a)}

Pada judul (2a) terdapat ketidakefektifan karena ketidakhematan. Kata dalam tidak diperlukan karena tanpa kata dalam pun makna semantis judul tersebut tidak berubah.

\section{Kesalahan Penerapan Kaidah Ejaan}

Pada judul (2a) kata efektifitas seharusnya efektivitas. Kata efektivitas merupakan serapan dari kata efektiviteit (Belanda). Dalam bahasa Inggris bunyi yang berubah 
menjadi -tas ialah bunyi -ty, misalnya kata aktivitas merupakan serapan dari kata activity.

Pada judul (2a) terdapat kata Santri Usia 13-15 Tahun; maksudnya, santri yang berusia 13sampai dengan 15 tahun. Tanda baca pengganti kata sampai dengan seharusnya tanda pisah (-), bukan tanda hubung (-).

Tanda koma dipakai di antara bagisn-bagian alamat. Perbaikan kasus (2a) adalah sebagai berikut DI PONDOK PESANTREN ASSALAFIYAH, DESA LUWUNGRAGI, KECAMATAN BULAKAMBA, KABUPATEN BREBES.

Alternatif Pembenahan Judul (2a)

EFEKTIVITAS PENGGUNAAN METODE SOROGAN TERHADAP KEMAMPUAN MEMBACA KITAB FATHUL AL-QORIB SANTRI USIA 13--15 TAHUN DI PONDOK PESANTREN ASSALAFIYAH, DESA LUWUNGRAGI, KECAMATAN BULAKAMBA, KABUPATEN BREBES

\section{Kasus Abstrak (2b)}

Secara umum Pesantren memiliki beberapa macam metode yang digunakan dalam kegiatan pembelajaran kitab kuning, salah satunya adalah metode sorogan, dimana metode ini dilakukan secara tatap muka langsung antara kyai/ustadz dan santri.

\section{Analisis Kasus (2b)}

Pada kasus (2b) terdapat dua kesalahan pemilihan kata, 3 kesalahan penyusunan kalimat, dan dua kesalahan penerapan kaidah ejaan.

\section{Kesalahan Pemilihan Kata (2b)}

Kata di mana berfungsi sebagai kata tanya. Akan tetapi, pada kalimat (2b) kata di mana tidak digunakan sebagai kata tanya sehingga perlu dihilangkan. Kata tatap muka pada kalimat (2b) bermakna bersemuka;berhadapan muka. Jadi, secara tersirat telah mengandung pengertian langsung sehingga kata tatap muka langsung ,diefektifkan menjadi tatap muka.

\section{Kesalahan Penerapan Kaidah Ejaan (2b)}

Pada kalimat (2b) kata Pesantren tidak memakai huruf awal kapital karena tidak diikuti nama pesantren. Huruf kapital atau huruf besar, di antaranya, digunakan sebagai huruf pertama nama resmi badan, lembaga pemerintahan dan ketatanegaraan, serta nama dokumen, misalnya Universitas Terbuka, Pesantren Khusnul Khotimah.

Tanda koma dapat dipakai-untuk menghindari salah baca-di belakang keterangan yang terdapat pada awal kalimat. Kata secara umum pada kalimat (2b) 
adalah keterangan yang terletak pada awal kalimat sehingga sesudah kata tersebut dapat diberi koma.

\section{Alternatif pembenahan kalimat (2b)}

Secara umum, pesantren memiliki beberapa macam metode yang digunakan dalam kegiatan pembelajaran kitab kuning, salah satunya adalah metode sorogan, yaitu metode yang dilakukan secara tatap muka antara kyai/ustadz dan santri.

\section{Kasus Abstrak (2c)}

Apabila metode ini dapat dilaksanakan dengan baik, maka akan menciptakan kemampuan membaca kitab dengan baik.

\section{Analisis Kasus (2c)}

Pada kasus (2c) terdapat satu kesalahan penyusunan kalimat.

\section{Kesalahan Penyusunan Kalimat (2c)}

Pada kalimat (2c) terdapat dua buah konjungsi, yaitu apabila dan maka. Dengan adanya dua konjungsi tersebut, tidak diketahui unsur mana sebagai induk kalimat dan unsur mana sebagai anak kalimat. Apabila metode ini dapat dilaksanakan dengan baik, maka akan menciptakan kemampuan membaca kitab dengan baik.... Dengan demikian, kedua unsur itu merupakan anak kalimat. Jadi, kalimat (2c) tidak mempunyai induk kalimat. Kalau begitu, satu konjungsi harus dihilangkan supaya satu dari dua unsur itu menjadi induk kalimat.

\section{Alternatif Pembenahan Kalimat}

Apabila metode ini dapat dilaksanakan dengan baik, akan menciptakan kemampuan membaca kitab dengan baik pula.

\section{Kasus Abstrak (2d)}

Kemampuan santri usia 13-15 tahun dalam membaca kitab fathul qorib di pondok pesantren assalafiyah desa luwungragi Kecamatan Bulakamba Kabupaten Brebes dirasakan kurang, padahal telah diterapkan metode sorogan oleh ustadz yang berkompeten di bidangnya.

\section{Analisis Kasus (2d)}

Pada kasus (2d) terdapat empat kesalahan penerapan kaidah ejaan.

\section{Kesalahan Penerapan Kaidah Ejaan (2d)}


Huruf kapital atau huruf besar dipakai sebagai huruf pertama semua kata untuk nama buku/kitab, majalah, surat kabar, dan judul karangan. Jadi, kitab fathul qorib seharusnya Kitab Fathul Qorib.

Huruf kapital dipakai sebagai huruf pertama nama resmi badan. Pada kalimat (2d), kata pesantren assalafiyah masih ditulis dengan huruf kecil pada awal kata; seharusnya huruf kapital, yaitu Pesantren Assalafiyah karena merupakan nama resmi badan/lembaga masyarakat.

Huruf kapital atau huruf besar dipakai sebagai huruf pertama nama geografi. Pada kalimat (2d), desa luwungragi masih ditulis dengan huruf kecil pada awal kata; seharusnya huruf kapital, yaitu Desa Luwungragi karena merupakan nama geografi.

\section{Tanda Pisah}

Tanda pisah dipakai di antara dua bilangan atau tanggal dengan arti 'sampai ke' atau 'sampai dengan'. Pada kalimat (2d) santri usia 13-15 tahun, maksudnya adalah santri yang berusia 13 sampai dengan 15 tahun. Jadi, seharusnya digunakan tanda pisah bukan tanda hubung. Pembetulannya adalah santri 13-15 tahun.

\section{Alternatif pembenahan $(2 \mathrm{~d})$}

Kemampuan santri usia 13--15 tahun dalam membaca Kitab Fathul Qorib di Pondok Pesantren Assalafiyah Desa Luwungragi Kecamatan Bulakamba Kabupaten Brebes dirasakan kurang, padahal telah diterapkan metode sorogan oleh ustadz yang berkompeten di bidangnya.

\section{Kasus Abstrak 3:}

(3a) Studi Perbandingan Penggunaan Metode Problem Solving Dan Metode Ceramah Terhadap Hasil Belajar Siswa Pada Mata Pelajaran Pendidikan Agama Islam (PAI) Kelas X Di Sekolah Menengah Atas (SMA) Negeri 1 Arjawinangun

(3b)Penggunaan metode yang kurang tepat dalam proses pembelajaran dapat mengakibatkan akfivitas siswa di kelas juga menjadi kurang dan terhambat sehingga pemahaman siswa akan materi yang disampaikan tidak dapat diserap sepenulmya sehingga hasil belajamya pun berkurang.

(3c) Metode yang digunakan dalam penelitian ini adalah metode kuantitatif dengan mengumpulkan data observasi, tes dan dokumentasi. 


\section{Kasus Abstrak (3a)}

Studi Perbandingan Penggunaan Metode Problem Solving Dan Metode Ceramah Terhadap Hasil Belajar Siswa Pada Mata Pelajaran Pendidikan Agama Islam (PAI) Kelas X Di Sekolall Menengah Atas (SMA) Negeri 1 Arjawinangun

\section{Analisis Kasus (3a)}

Pada kasus (3a) terdapat dua kesalahan penerapan kaidah ejaan.

\section{Kesalahan Penerapan Kaidah Ejaan (3a)}

Huruf kapital dipakai sebagai huruf pertama semua kata (termasuk semua unsur kata ulang sempurna) di dalam nama buku, majalah, surat kabar, dan judul karangan kecuali kata seperti di, ke, dari, dan, yang, dan untuk yang tidak terletak pada posisi awal. Pada judul (3a) terdapat kata dan, terhadap, pada, di . Keempat kata tersebut termasuk kata depan (preposisi) yang terdapat pada judul karangan (karya ilmiah) yang tidak terletak pada posisi awal. Jadi, keempat preposisi tersebut seharusnya ditulis dengan huruf kecil pada awal kata.

Huruf miring dalam cetakan dipakai untuk menuliskan kata nama ilmiah atau ungkapan asing kecuali yang telah disesuaikan ejaannya. Problem solving adalah ungkapan asing sehingga harus ditulis dengan huruf miring.

\section{Alternatif pembenahan kalimat (3a)}

Studi Perbandingan Penggunaan Metode Problem Solving dan Metode Ceramah terhadap Hasil Belajar Siswa pada Mata Pelajaran Pendidikan Agama Islam (PAI) Kelas X di Sekolall Menengah Atas (SMA) Negeri 1 Arjawinangun.

\section{Kasus Abstrak (3b)}

Penggunaan metode yang kurang tepat dalam proses pembelajaran dapat mengakibatkan aktivitas siswa di kelas juga menjadi berkurang dan terhambat sehingga pemahaman siswa akan materi yang disampaikan tidak dapat diserap sepenuhnya sehingga hasil belajarnya pun berkurang.

\section{Analisis Kasus (3b)}

Pada kasus (3b) terdapat satu kesalahan penyusunan kalimat, dan satu kesalahan penataan penalaran.

\section{Kesalahan Penyusunan Kalimat (3b)}

Karya ilmiah harus menggunakan kalimat efektif. Ciri-ciri kalimat efektif di antaranya adalah kehematan. Hemat dalam mempergunakan kata, frasa, atau bentuk lain yang dianggap tidak perlu, tetapi tidak menyalahi kaidah tata bahasa. Hal ini karena 
penggunaan kata yang berlebih akan mengaburkan maksud kalimat atau kalimat itu menjadi monoton. Pada kalimat (3b) terdapat pengulangan kata sehingga yang membuat kalimat tersebut menjadi tidak efektif karena ketidakhematan.

\section{Kesalahan Penataan Penalaran (3b)}

Pada kalimat (3b) terdapat klausa pemahaman siswa akan materi yang disampaikan tidak dapat diserap sepenuhnya. Pada klausa tersebut yang tidak dapat menyerap materi sepenuhnya, tentu saja, adalah siswa bukan pemahaman siswa sehingga klausa tersebut menjadi tidak logis.

\section{Alternatif Pembenahan Kalimat (3b)}

Penggunaan metode yang kurang tepat dalam proses pembelajaran dapat mengakibatkan aktivitas belajar, pemahaman materi, dan hasil belajar siswa di kelas pun menjadi berkurang dan terhambat karena materi yang disampaikan tidak dapat diserap dengan baik.

\section{Kasus Abstrak (3c)}

Metode yang digunakan dalam penelitian ini adalah metode kuantitatif dengan mengumpulkan data observasi, tes dan dokumentasi.

\section{Analisis Kasus (3c)}

Pada kasus (3c) terdapat satu kesalahan pembentukan kata.

\section{Kesalahan Pembentukan Kata (3c)}

Tanda koma dipakai di antara unsur-unsur dalam suatu perincian atau pembilangan. Misalnya, saya membeli kertas, pena, dan tinta. Pada kalimat (3c) tidak ada koma (,) sebelum rincian terakhir, yaitu data observasi, tes dan dokumentasi. Pembetulannya adalah data observasi, tes, dan dokumentasi.

\section{Alternatif Pembenahan Kalimat (3c)}

Metode yang digunakan dalam penelitian ini adalah kuantitatif dengan mengumpulkan data observasi, tes, dan dokumentasi.

\section{Kasus Abstrak 4:}

(4a) Tokoh agama didefinisikan sebagai seseorang yang berilmu terutamanya dalam hal perkaitan dalam islam, ia_ wajar dijadikan sebagai role-model dan tempat rujukan ilmu bagi orang lain.

(4b) Di samping itu, ia juga mempunyai identiti, mentaliti, dan moraliti yang hebat dalam dirinya berbanding orang lain. 
(4c) Kebiasaannya figura ataupun tokoh ini disanjungi dan di jadikan ikutan yang baik kerana mereka kaya dengan nilai-nilai positif.

(4d) Dari hasil yang dilakukan Tokoh Agama dalam Pembinaan Ahlakul Karimah Ibuibu Buruh Tani di Desa Karangkerta Kecamatan Tukdana Kabupaten Indramayu menunjukkan hasil 49\%, sedangkan sisanya 51\% kategori Baik.

\section{Analisis Kasus Abstrak (4a)}

Tokoh agama didefinisikan sebagai seseorang yang berilmu terutamanya dalam hal perkaitan dalam islam, ia wajar dijadikan sebagai role-model dan tempat rujukan ilmu bagi orang lain.

\section{Analisis Kasus (4a)}

Pada kasus (2b) terdapat 1 kesalahan pembentukan kata, 2 kesalahan pemilihan kata, 1 kesalahan penyusunan kalimat, dan 2 kesalahan penerapan kaidah ejaan.

\section{Kesalahan Pembentukan Kata (4a)}

Kata terutamanya hanya digunakan dalam bahasa lisan atau bahasa cakapan yang tidak resmi. Kata seperti ini, mungkin, merupakan pengaruh bahasa daerah Jawa utamane atau sing utama. Dalam bahasa yang baku, harus digunakan kata terutama, tanpa akhiran -nya.

\section{Kesalahan Pemilihan Kata (4a)}

Kata perkaitan dalam Islam maksudnya, kemungkinan, adalah berkaitan dengan Islam ; akan lebih efektif bila disederhanakan menjadi keislaman.

Pada kalimat (4a) kata ia tidak diperlukan karena sudah ada kata tokoh agama yang sama-sama berfungsi sebagai subjek. Jadi, subjek yang sama pada anak kalimat seharusnya dihilangkan.

\section{Kesalahan Penyusunan Kalimat (4a)}

Klausa ... ia wajar dijadikan sebagai role-model dan tempat rujukan ilmu bagi orang lain... menyatakan hubungan akibat dengan klausa sebelumnya ... Tokoh agama didefinisikan sebagai seseorang yang berilmu terutamanya dalam hal perkaitan dalam islam ... hubungan akibat dapat diperjelas dengan kata sehinggga dengan tanpa tanda baca koma (,) sebelumnya.

\section{Kesalahan Penerapan Kaidah Ejaan (4a)}

Tanda koma dipakai untuk mengapit keterangan tambahan yang sifatnya tidak membatasi. Pada kalimat (4a), kata terutama merupakan keterangan tambahan yang 
sifatnya tidak membatasi. Jadi, seharusnya diberi tanda koma (,) untuk mengapit kata terutama.

Huruf awal kapital dipakai pada nama agama. Jadi kata islam (kasus 4a) seharusnya Islam.

\section{Alternatif Pembenahan Kalimat (4a)}

Kalimat (4a)Tokoh agama didefinisikan sebagai seseorang yang berilmu, terutama, dalam hal keislaman sehingga wajar jika dijadikan sebagai role-model dan tempat rujukan ilmu bagi orang lain.

\section{Kasus Abstrak (4b)}

Di samping itu, ia juga mempunyai identiti, mentaliti, dan moraliti yang hebat dalam dirinya berbanding orang lain.

\section{Analisis Kasus (4b)}

Pada kasus (4b) terdapat satu kesalahan pembentukan kata dan tiga kesalahan pemilihan kata.

\section{Kesalahan Pembentukan Kata}

Kata identiti, mentaliti, dan moraliti tidak baku; yang baku adalah identitas, mentalitas, dan moralitas. Bandingkan dengan kata imunitas yang merupakan serapan dari kata immunity (Inggris).

\section{Kesalahan Pemilihan Kata}

Kata ia pada penulisan karya ilmiah terkesan kurang resmi; seharusnya digunakan kata dia.

Kata dalam dirinya tidak diperlukan karena sudah direpresentasikan oleh kata ia(dia).

Kata berbanding kurang lazim digunakan dalam konteks kalimat (4b), sebaiknya digunakan konstruksi idiomatis dibandingkan dengan.

\section{Alternatif Pembenahan Kalimat (4b)}

Di samping itu, dia juga mempunyai identitas, mentalitas, dan moralitas yang hebat dibandingkan dengan orang lain.

\section{Kasus Abstrak (4c)}

Kebiasaannya figura ataupun tokoh ini disanjungi dan di jadikan ikutan yang baik kerana mereka kaya dengan nilai-nilai positif. 


\section{Analisis Kasus (4c)}

Pada kasus (4c) terdapat tiga kesalahan pembentukan kata dan tiga kesalahan pemilihan kata.

\section{Kesalahan Pembentukan Kata (4c)}

Kata disanjungi dalam konteks kalimat (4c) kurang tepat, seharusnya disanjung.

Pada kalimat (4c) kata di jadikan adalah bentukan kata yang salah karena bukan $d i$ preposisi (kata depan), tetapi di- prefiks atau awalan. Jadi, penulisannya seharusnya disambung, yaitu dijadikan.

Kata kerana lazim digunakan pada bahasa Melayu-Malaysia, tetapi tidak lazim digunakan dalam konteks berbahasa Indonesia resmi/ilmiah; seharusnya digunakan kata karena.

\section{Kesalahan Pemilihan Kata (4c)}

Kata figura pada kalimat (4c), mungkin, hanya salah ketik karena berdasarkan konteks kalimatnya, seharusnya digunakan kata figur.

Kata ikutan hanya digunakan pada ragam percakapan tidak resmi. Pada konteks kalimat (4c) kata yang tepat adalah teladan.

Berdasarkan makna semantisnya, kata kebiasaannya pada kalimat (4c) tidak tepat karena kebiasaannya berarti sesuatu yang biasa dikerjakan oleh seseorang. Padahal yang dimaksud adalah biasanya karena mengacu pada sesuatu yang lazim, umum.

\section{Alternatif pembenahan $(4 \mathrm{c})$}

Biasanya, figur atau tokoh ini disanjung dan dijadikan teladan yang baik karena mereka kaya dengan nilai-nilai positif.

\section{Kasus Abstrak (4d)}

Dari hasil yang dilakukan Tokoh Agama dalam Pembinaan Ahlakul Karimah Ibuibu Buruh Tani di Desa Karangkerta Kecamatan Tukdana Kabupaten Indramayu menunjukkan hasil 49\%, sedangkan sisanya 51\% kategori Baik.

\section{Analisis Kasus (4d)}

Pada kasus (4d) terdapat 1 kesalahan pemilihan kata, 1 kesalahan penyusunan kalimat, dan 1 kesalahan penerapan kaidah ejaan.

\section{Kesalahan Pemilihan Kata (4d)}

Pada kalimat (4d) terdapat pleonasme. Terdapat kata-kata yang tidak perlu digunakan karena ada pengulangan kata hasil. Kata hasil yang kedua sebenarnya tidak diperlukan lagi sebab maknanya sudah terkandung dalam kata hasil yang pertama. 


\section{Kesalahan Penyusunan Kalimat (4d)}

Kalimat yang benar dalam ragam baku paling sedikit harus memiliki subjek dan predikat, kecuali kalimat perintah atau ujaran yang merupakan jawaban pertanyaan. Biasanya, kalimat yang subjeknya tidak jelas itu terdapat dalam kalimat rancu (kacau), antara lain, kalimat yang berpredikatkan kata kerja aktif, tetapi subjeknya didahului kata depan. Subjek kalimat aktif yang didahului kata depan pada seperti pada kalimat (4d) menyebabkan hilangnya status subjek sehingga makna menjadi tidak jelas, kabur, bahkan dapat menimbulkan berbagai tafsiran.

\section{Kesalahan Penerapan Kaidah Ejaan (4d)}

Tanda koma dipakai di antara (a) nama dan alamat, (b) bagian-bagian alamat, (c) tempat dan tanggal, serta (d) nama tempat dan wilayah atau negeri yang ditulis berurutan. Pada kalimat (4d) terdapat bagian-bagian alamat ... Desa Karangkerta Kecamatan Tukdana Kabupaten Indramayu menunjukkan ..., seharusnya di antara bagian-bagian kalimat tersebut dibubuhi tanda koma ... Desa Karangkerta, Kecamatan Tukdana, Kabupaten Indramayu , menunjukkan ....

\section{Alternatif Pembenahan Kalimat (4d)}

Hasil yang dilakukan tokoh agama dalam pembinaan akhlakul karimah Ibu-ibu buruh tani Desa Karangkerta, Kecamatan Tukdana, Kabupaten Indramayu adalah 49\%, sedangkan sisanya $51 \%$ kategori baik.

\section{Simpulan}

Simpulan yang dapat ditarik dari penelitian ini dapat disebutkan sebagai berikut. Dari 24 abstrak skripsi mahasiswa PAI, yang dijadikan data penelitian utama sebanyak 71 kalimat. Berdasarkan hasil analisis kesalahan dari data tersebut, ditemukan 31 kesalahan pembentukan kata, 61 kesalahan pemilihan kata, 62 kesalahan penyusunan kalimat, 11 kesalahan penataan penalaran, dan 105 kesalahan penerapan kaidah ejaan.

Adapun bentuk-bentuk kesalahan berdasarkan jenis kesalahannya adalah sebagai berikut. (1) Kesalahan pembentukan kata, di antaranya, meliputi kesalahan penulisan kata serapan, penulisan klitika, tidak dapat membedakan $d i$ - sebagai awalan dan $d i$ sebagai preposisi, dan kesalahan penulisan kata turunan yang berimbuhan meng-. (2) Jenis kesalahan pemilihan kata, di antaranya meliputi kesalahan pengulangan kata yang tidak diperlukan pada satu kalimat, adanya pleonasme, penggunaan kata yang tidak hemat/cermat, pengulangan subjek yang sama pada klausa yang berbeda, dan 
penggunaan subjek penulis/peneliti dengan gaya kalimat aktif. (3) Selanjutnya jenis kesalahan penyusunan kalimat di antaranya meliputi ketidakketepatan penggunaan konjungsi antarkalimat dan intrakalimat, ketidakjelasan subjek karena kalimat didahului oleh preposisi, kalimat yang penyusunannya terlalu kompleks sehingga tidak jelas maksudnya, dan penggunaan dsb/dll yang tidak tepat. (4) Jenis kesalahan berikutnya adalah dalam penataan penalaran, pada umumnya, meliputi penggunaan kata-kata yang bermakna ambigu dan tidak logis. (5) Terakhir, adalah jenis kesalahan penerapan kaidah ejaan, yaitu meliputi ketidakpahaman dalam membedakan tanda hubung dan tanda pisah, penggunaan huruf kapital dan huruf miring; penggunaan tanda baca koma dan titik; kesalahan penulisan kata ( terutama berkaitan dengan penulisan kata yang berasal dari bahasa Arab, tampaknya pembakuan dalam bahasa Indonesia untuk katakata tersebut kurang disosialisasikan dengan baik atau telah diketahui, tetapi dirasa aneh/kurang cocok dengan kelaziman pelafalan/penulisan dalam bahasa Arabnya).

Temuan lain, pada 24 abstrak skripsi secara umum, di antaranya, terdapat plagiasi penulisan abstrak sekitar $80 \%$ antara abstrak nomor 2 dan nomor 24 , yang berbeda hanya pada kalimat terakhir saja. Di samping itu, ada delapan abstrak dengan penulisan klausa akhirnya menggunakan kata-kata yang sama, tetapi hitungan persentasenya berbeda. Terdapat pula delapan judul skripsi yang diawali dengan kata "pengaruh".

\section{Daftar Pustaka}

Alwasilah, A. C. 2002. Pokoknya Kualitatif: Dasar-dasar Merancang dan Melakukan Penelitian Kualitatif. Jakarta: Pustaka Jaya.

Arifin, Zaenal, Farid Hadi. 2001. 1001 Kesalahan Berbahasa.Jakarta: Akademika Pressindo.

Arikunto. S. 1991. Prosedur Penelitian. Suatu Pendekatan Praktis. Jakarta: Rineka Cipta.

Applebee.AN. 1981. Writing in the Secondary School: English and the Content Areas. NCTE Research Report No. 21.

Chaer, Abdul. 2011. Ragam Bahasa Ilmiah. Jakarta : PT Asdi Mahasatya.

Departemen Pendidikan dan Kebudayaan.1998. Kamus Besar Bahasa Indonesia. Jakarta: Balai Pustaka.

--------. 2008. EYD Plus. Jakarta: Limas.

Kurniawan, Irwan. 2015. EYD Ejaan yang Disempurnakan. Bandung: Nuansa Cendekia.

Rohmadi, Muhammad dan Aninditya Sri Nugraheni. 2011. Belajar Bahasa Indonesia: Upaya Terampil Berbicara dan Menulis Karya Ilmiah. Surakarta: Cakrawala Media..

Sabariyanto, Dirgo. 1999. Mengapa Disebut Bentuk Baku dan Tidak Baku? Yogyakarta: Mitra Gama Widya.

............2002. Kata-kata yang Patut Anda Pahami. Yogyakarta: Gama Media. 
Sobarna, Cece. Tanpa Tahun. "Bahasa sebagai Pendidikan Karakter". Jakarta: Badan Pembinaan dan Pengembangan Bahasa.

Sutikno. 2010. Pengembangan Model Sinektik pada Pembelajaran Menulis Berkonteks Multikultural dalam Pembentukan karakter siswa. UNNES: Pascasarjana.

Suyitno, Imam. 2012. Menulis Makalah dan Artikel.Bandung: PT Refika Aditama.

Tarigan, H.G. 1992. Menulis sebagai Suatu Keterampilan Berbahasa. Bandung: Angkasa.

Tiedt, I. M. 1989. Writing From Topicto Evaluation. London: Allyn and Bacon.

Tim Penyusun KBBI. 2008. Kamus Besar Bahasa Indonesia. Balai Pustaka: Jakarta.

Umaemah, A. 2010. Aplikasi Teknik Menulis Kolaboratif dalam Peningkatan Kemampuan Menulis Bahasa Inggris.PTK pada IAIN Syekh Nurjati Cirebon: tidak diterbitkan.

Wijaya, Putu. 2012. Tempo: "Karakter dalam Bahasa". Jakarta: Tempo. 